\title{
Community Empowerment and Sustainable Tourism Development: The Mediating Role of Community Support for Tourism
}

\author{
Shahrukh Khalid ${ }^{1}$, Muhammad Shakil Ahmad ${ }^{2,3}{ }^{1}$, T. Ramayah ${ }^{4,5}$, Jinsoo Hwang ${ }^{6}$ and \\ Insin $\operatorname{Kim}^{7, *}$ \\ 1 Department of Management Sciences, Bahria University Islamabad 46220, Pakistan; shaari20@gmail.com \\ 2 Department of Management Sciences, COMSATS University Islamabad, Attock 43600, Pakistan; \\ onlyshakil@gmail.com \\ 3 College of Hotel \& Tourism Management, Kyung Hee University, Seoul 130-701, Korea \\ 4 School of Management, Universiti Sains Malaysia, Penang 11800, Malaysia; ramayah@usm.my \\ 5 Internet Innovation Research Center, Newhuadu Business School, Minjiang University, \\ Fuzhou 350108, China \\ 6 The College of Hospitality and Tourism Management, Sejong University, Seoul 143-747, Korea; \\ jhwang@sejong.ac.kr \\ 7 Department of Tourism and Convention, Pusan National University, Busan 46241, Korea \\ * Correspondence: insinkim@pusan.ac.kr; Tel.: +82-51-510-3005
}

Received: 26 September 2019; Accepted: 6 November 2019; Published: 7 November 2019

\begin{abstract}
Though community empowerment and sustainable tourism development (STD) have been discussed in the existing literature, little research has focused on the elaborate mechanisms between these two variables. Therefore, the present study examines the relationship between community empowerment and STD, along with the mediating role played by community support for tourism. Using social exchange theory, this research establishes theoretical relationships between vital variables for STD. A survey of empirical study was undertaken, and data were collected from 353 local residents in the northern area of Pakistan. The results for data analyses demonstrated a significant relationship between community empowerment and STD initiatives, and community support for tourism was shown to partially mediate the relationship between the two variables. The findings imply that high community empowerment enables the community to establish successful sustainable tourism development through local people's support for tourism. This study contributes theoretically to identifying the idea that community members' support for tourism has a crucial function bridging the link from community empowerment to sustain tourism in a local area.
\end{abstract}

Keywords: sustainable tourism development; community empowerment; community support; community-based tourism; Pakistan

\section{Introduction}

In the last decade, the World Tourism Organization has launched tourism campaigns and sustainable tourism/poverty eliminating programs as tools to uplift the economic benefits in marginalized communities [1-3]. In particular, it has been extensively recognized that community-based tourism can improve the communities' economic status [4]. Local people have preserved their traditional culture and society, leading to a rise in tourist interest in local cultures. Additionally, residents' environmental awareness is increased through various unique and uncommon species has created an awareness to conserve natural resources in order to provide beautiful tourism experiences to tourists [5]. That is, community-based tourism is an effective approach to ensure sustainable tourism 
development (STD) through the process of sharing benefits among all community members and the conservation of natural resources [6]. In less developed countries, community-based tourism is an alternative to mass tourism, which Zhao and Timothy [3] argue not only generates financial resources but also helps to mitigate the negative effects of mass tourism such as environmental damage. In other words, successful community-based tourism helps to enhance local people's quality of life by reducing poverty and preserving natural and cultural resources in the community [7].

In the least developed communities, community-based tourism projects have been mostly initiated by non-governmental organizations (NGOs) or governments. However, since tourism projects have a high risk of failing if the community does not control or support the post-implementation [8], residents should participate in the process of STD. Additionally, for the community residents' involvement in STD, the concept of residents' empowerment should be considered [1,9].

Within the tourism literature, a consensus has been reached over the last 30 years on residents' involvement in tourism activities to ensure sustainability [1,10-13] because community plays a central role in planning sustainable and socially responsible tourism [14]. Though previous studies have suggested that STD initiatives are not successful without the cooperation, support, goodwill and participation of local residents, researchers are still exploring and categorizing the resident attitudes witnessed and reported. Therefore, it is necessary to clearly establish the causal relationship between empowerment and residents' participation that leads to successful STD establishment.

In recent community-based tourism research, community power and empowerment have been considered crucial issues. Though empowerment has been considered important for community-based tourism, and numerous conceptual and qualitative studies have been examined on resident's empowerment, empirical evidence to measure empowerment remains lacking [15]. A creative approach for citizens' participation in community-based tourism should be adopted, and a proper model should be developed to ensure STD in the context of developed countries. For example, Li [16] noted the application of the community-based tourism concept in developing countries like China [17] but found that the studies only highlight community involvement in terms of the economic benefits of tourism while neglecting its other important elements.

Though community empowerment and sustainable tourism have been discussed in previous studies, focus has only rarely been directed at the elaborate mechanisms between them. The current study highlights the need for more research on resident's empowerment and how their support for tourism functions in the process of implementing community' STD. Therefore, the current study examines the relationship between community empowerment and STD, specifically the mediating role played by community support for tourism.

\section{Literature Review}

\subsection{Community-Based Tourism and STD}

Even though tourism is an effective way to decrease poverty by providing economic benefits to local communities, tourism development has damaged traditional culture and changed residents' livelihood. In the early stages of tourism development, local people endure negative effects on social, cultural and environmental factors instead of gaining their economic benefits [5]. Therefore, scholars have introduced community-based tourism to provide local people a high quality of life, driving a greater value of traditional culture and conserving the natural environment through tourism planning and management (e.g., [18-20]), thus leading to sustainable tourism.

STD has been widely examined in tourism planning and development fields. Compared with tourism development in the early stages, STD not only provides economic growth in communities but also fulfills tourists' needs, enhances residents' life satisfaction, and preserves the physical environment for future generations [21-24]. That is, community-based tourism has been considered a critical way to accomplish successful STD [7,23]. 
In the planning and management of community-based tourism, since local residents who directly interact with tourists and indirectly are major stakeholders, it is essential to have a positive perception and attitude toward tourism. Social exchange theory explains that local residents determine their support for tourism development depending on their' perceptions of the positive or the negative impacts [23]. In the process of forming residents' perception of tourism's impact and attitude toward tourism, the concept of empowerment functions as a critical predictor [9]. Therefore, for STD in communities, it is important to balance the power in the tourist-resident relationship by enhancing residents' empowerment.

\subsection{Community Empowerment}

Empowerment is described as the power to do something on an individual or collective level [25]. While empowerment can be a useful tool to improve the capacities and assets of local communities, both individually and collectively, community empowerment needs community members' engagement and collective action rather than individual action [25].

In the tourism development field, community empowerment is vital element in implementing STD [9]. Historically, scholars (e.g., [4,26]) have highlighted the strong connection between empowerment of local people and community well-being via tourism. Though several studies have focused on general power and community participation without considering community empowerment and its contribution to sustainable tourism [15,27], residents' empowerment is a prerequisite for STD $[28,29]$. Community empowerment is synonymous with giving power and voice to marginalized groups and local communities, so it is based on the collective action and engagement of all community members rather than individual acts [25]. Sutawa [30] asserted that the community empowerment process should include meeting the real and felt needs of the community, better access to resources, managing local organizations, and socially controlling environmental aspects through developing the community's capacity. Meanwhile, Sood, Lynch, and Anastasiadou [31] argued that a top-down tourism planning approach results in conflicting interests between tourism planners and rural communities that hinder community engagement and eventually overall tourism development. Moreover, top-down tourism planning causes governments and other stakeholders to retain power in their hands and to avoid involving residents in decision making [32,33].

The importance of residents' empowerment for STD has been emphasized by many scholars [34-36]. Furthermore, the effect of community empowerment on STD can be explained by social exchange theory. The critical concept of social exchange theory is social power because it determines residents' ability to take advantage of tourism outcomes. More social power to the community leads to better decision making and opportunities to build local capacity. That is, empowered communities are better equipped to gain potential benefits from STD $[37,38]$. Therefore, we postulate that:

Hypothesis 1 (H1). Community empowerment positively influences STD.

\subsection{Community Support for Tourism}

Previous studies have suggested that STD initiatives would not be successful without the local residents' cooperation, support, goodwill, and participation. A number of researchers in the tourism field have investigated residents' attitudes towards tourism in numerous regions of Asia, Australia, North America, Africa and Europe [39-41]. Similarly, Gursoy and Jurowski, [42] collected data from the residents of Virginia through a survey and identified that the level of concern, utilization of resources, perceived benefits, and costs from tourism are key factors in determining residents' support for tourism.

In community-based tourism research concerning local people' attitudes toward tourism, power relation and trust are considered core ideas [43]. An imbalanced power relationship leads to residents' negative perception toward tourism in the host community [44]. Residents' level of control over tourism initiatives and power relations are key elements in determining residents' tourism impact perception. 
Moreover, when local residents participate in tourism planning and management, they have a positive attitude to tourism development and support for tourism [45]. Therefore, we postulate that:

Hypothesis 2 (H2). Community empowerment positively influences community support for tourism.

A study conducted in Botswana by Sebele [7] demonstrated the importance of the local community's participation and involvement in tourism planning and management in ensuring community empowerment and the conservation of natural resources. Involving the community in the process of tourism development increases their awareness of the costs and benefits of tourism. Communities with opportunities to participate in decisions affecting their lives mobilize their capacity and pride in their traditional culture and heritage [4]. Sustainable tourism is difficult to develop without the support of local residents. Thus, local residents' support is a critical factor for STD. Researchers have emphasized residents' support for STD. Local residents' involvement in decision making and a positive attitude towards tourism are essential for tourism sustainability [46]. The Global Sustainable Tourism Criteria (GSTC-D, 2013) observed that sustainability has a significant impact on the lives of local communities. Tourism development is perceived as being more appropriate by local communities when they are involved in tourism planning [47]. Therefore, we postulate that:

Hypothesis 3 (H3). Community support for tourism positively influences STD.

Empowered communities are able to gain better benefits from tourism development opportunities and utilize those opportunities in an effective way [48,49]. Sustainable tourism cannot be achieved until community members actively support tourism development [50,51]. Governments and markets require community support and participation in order to implement strategies for STD [35,52].

The previous literature has adopted a qualitative approach to demonstrate the importance of community empowerment for STD. Nunkoo and Ramkission [53] proposed checking community support as a potential mediator for sustainable tourism. They suggested that there is also a need to check on the proper channel from community empowerment to STD through mediation. The previous literature has showed the mediating effect of support for tourism in the relationship between perceived impacts of tourism and support for tourism planning. Nunkoo and So [32] suggested support for tourism as a dependent variable of trust in government and recommended to empirically test it in order to establish its mechanism. Nunkoo and Ramkission [53] identified power as one of the factors that determines the community support for tourism. Therefore, we postulate that:

Hypothesis 4 (H4). Community support for tourism mediates the effect of community empowerment on STD.

The hypothesized model of the study is presented in Figure 1. 


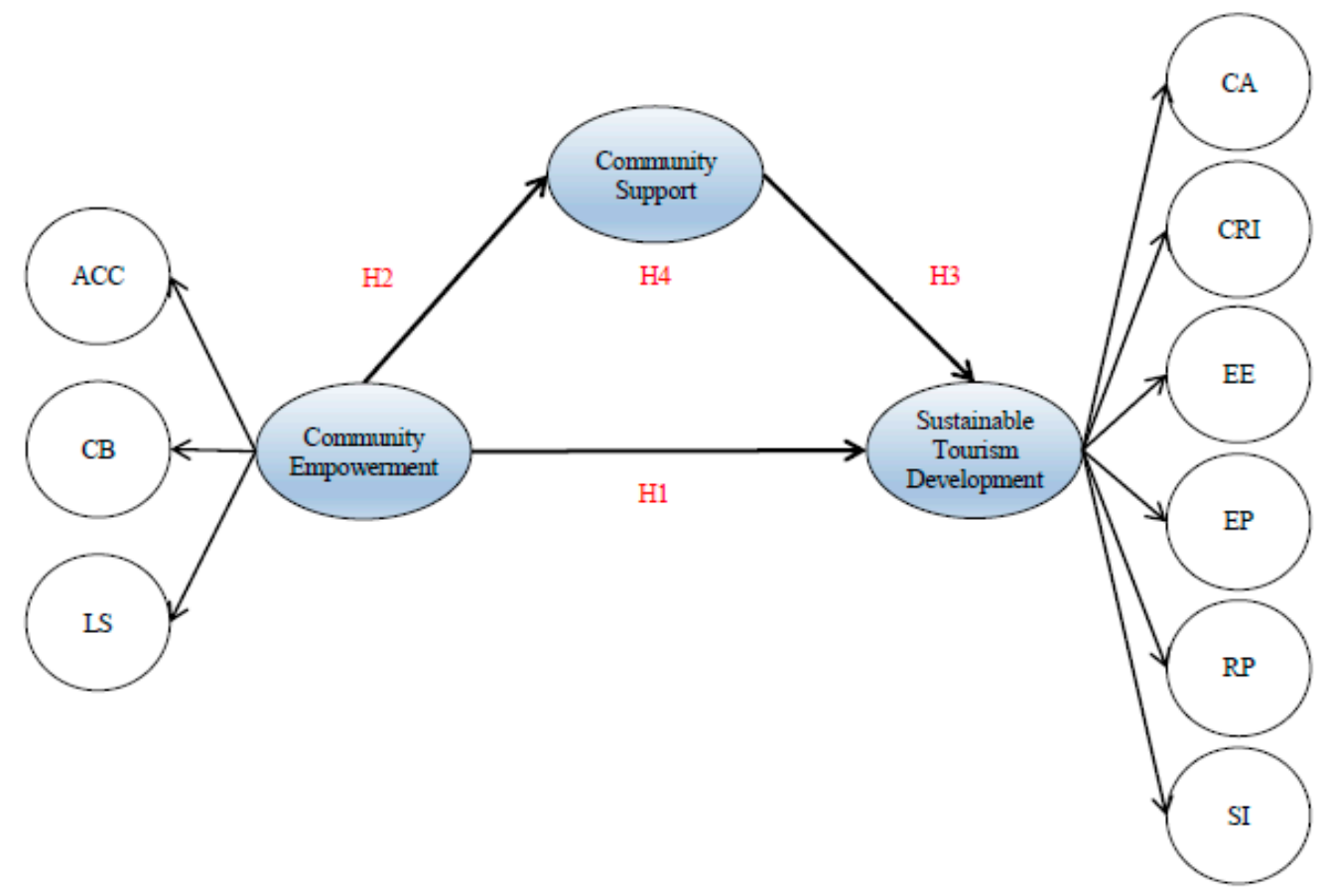

Figure 1. Research Framework. Note: ACC—accountability; CB-capacity building; LS—leader support; CA—cultural awareness; CRI—community resource identification; EE-environmental education; EP—economic planning; RP—resource preservation; SI—stakeholder inclusion.

\section{Method}

\subsection{Measures}

The scale for community empowerment consists of three dimensions including accountability (ACC), capacity building (CB) and leaders' support (LS) adopted from Satarat [54], rated on a 5-point Likert scale. CB refers to a local community's increased ability, skills, knowledge and resources to strengthen themselves and enable them to cope with local problems faced [55]. ACC is defined as equal voice and opportunities for all community members in the local development process [56]. Ellis and Sheridan [6] defined LS as leadership which emerges through consensus and serves the interest of diverse groups within community.

Community support for the tourism scale, which consists of six items, was adopted from the study of Nunkoo and So [32]. Similarly, the items of the STD construct were adopted from [57]. This construct - which has six dimensions of cultural awareness (CA; two items), community resource identification (CRI; three items), environmental education (EE; six items), economic planning (EP; six items), resource preservation (RP; eight items) and stakeholder inclusion (SI; six items)—consists of 31 items measured on a 5-point Likert scale. CA represents the idea that responsible authorities must consider the inputs of various stakeholders including local residents, community, industry, tourists and special interest groups during the formulation of tourism policies and strategies [58]. CRI refers to community member's awareness and knowledge about resources that contribute positively towards tourism development in area [59]. EE refers to tourism education and training programs for the community's awareness of tourism impacts and agreement to STD [57]. The EP of sustainable tourism must integrate tourism with other economic activities while maximizing benefits and mitigating the social, cultural and environmental costs of tourism on long term [60]. RP refers to the efforts to maintain the present condition of natural and cultural resources [61]. SI refers to the identification of diverse stakeholder groups at the community level, increasing stakeholders' awareness and education about tourism, which is critical for the meaningful inclusion of stakeholders [57]. 


\subsection{The Research Area}

Figure 2 represents the map of northern area of Pakistan. It mainly consists of different tourist sites, namely Babusar top, Naran, Khaghan, Lulusar Lake, Fairy Meadows and Nori top. Near Hunza, this tourist site share border with China.

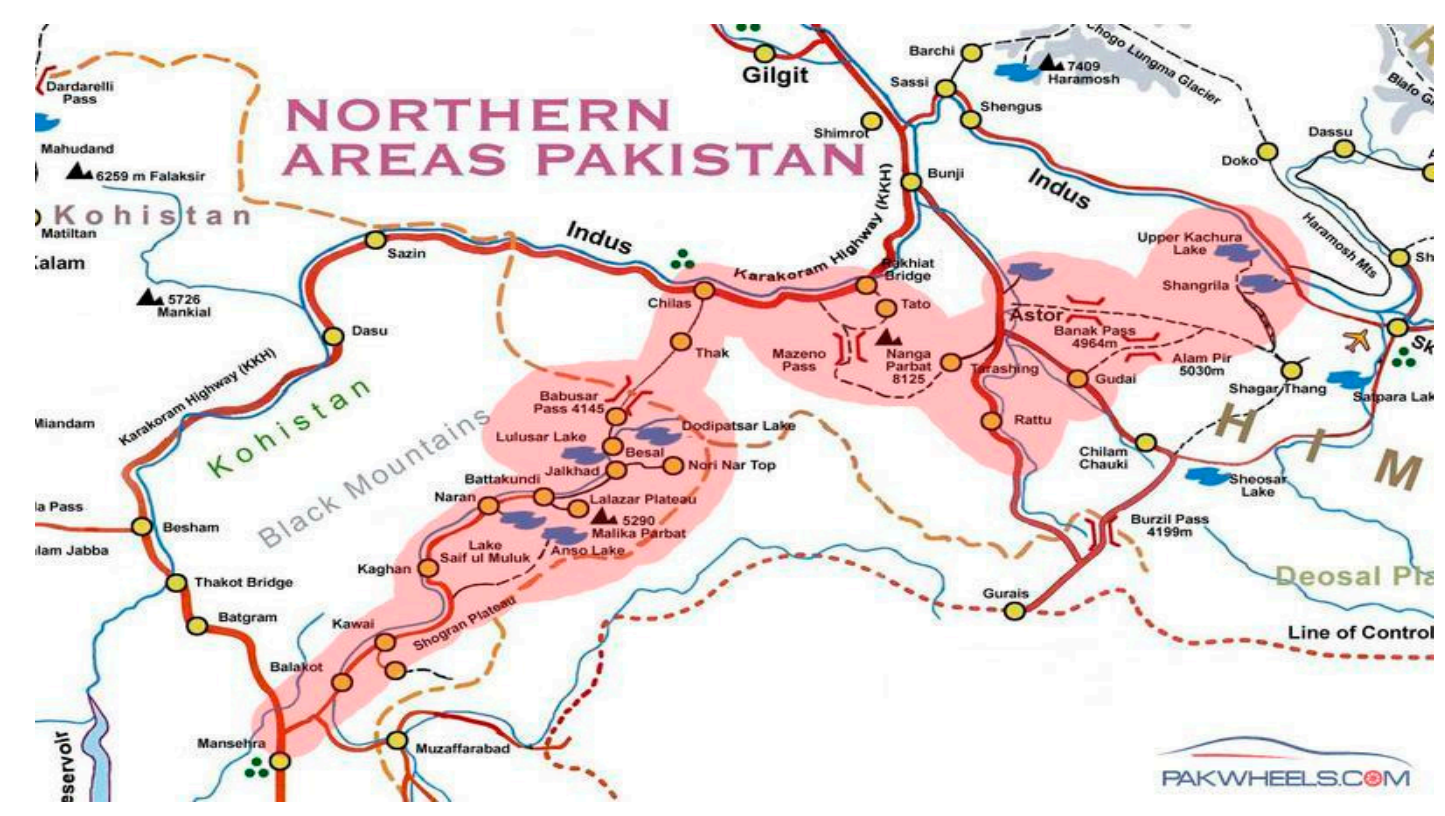

Figure 2. Map.

Most tourists are families, college/universities students and foreigners who are planning to spend their summer vacations (June, July and August) in the northern area of Pakistan. Most domestic tourists are from Southern Punjab (Rahim Yar Khan, Multan, Gujrat, Sailkot and Lahore) and Sindh (Karachi and Hyderabad). The distance of these areas from northern areas is about $1500-1700 \mathrm{~km}$, and tourists mostly travel using road transport, as only one airline that operates in the route has one or two flights per week. Most of the companies related to tourism announce discounted rates to attract more tourists in the region. The northern area of Pakistan is mostly hilly and consists of a variety of famous lakes (Ansoo Jheal, Sheoshar lake, Attabad lake, Rama lake and Fairy Meadows). Additionally, other tourist attractions in the region are the highest mountain ranges including Karakoram Range, the Himalayan mountain range (Nanga Parbat, globally ranked 9th in height) and the Hindu Kush mountain range. As the northern area is famous for cool weather, greenery and rainfall, tourists who visit the destination are satisfied with the travel and feel health benefits [62].

\subsection{Data Collection}

To empirically test the proposed research framework on the relationships between community empowerment, community support for tourism, and STD, a trained research team collected data from local community members, leaders and tour operators. The research team visited local community members twice to finalize the survey questionnaire and asked local residents to participate in the survey by receiving support from local leaders and tourist operators. Additionally, in-person data collection was conducted from the northern area of Pakistan, which consists of Naran, Khaghan, Giligt Baltistan, Hunza and Skardu. The inclusion criteria for the selection of these subjects were: (a) local residents (earning source is mostly from tourist related activities); (b) local leaders (locally elected union council members) and (c) tourist operators. In total, 400 local residents including local leaders and tour operators participated in survey; however, 47 responses were excluded, as most of them contained missing values and some portions were unfilled. Therefore, 353 responses were found to be useable for further data analysis processing. The respondent's profiles are presented in Table 1. 
Table 1. Profile of respondents.

\begin{tabular}{cccc}
\hline Characteristics & Categories & Frequency (N) & Percentage (\%) \\
\hline \multirow{2}{*}{ Gender } & Male & 205 & 58 \\
& Female & 148 & 41.9 \\
\hline \multirow{2}{*}{ Age } & $22-30$ & 86 & 24.36 \\
& $31-38$ & 93 & 26.35 \\
& $39-45$ & 63 & 17.84 \\
& $46-60$ & 51 & 14.44 \\
Resident Type & Older than 60 & 60 & 17.1 \\
& Community members & 183 & 51.84 \\
& Local leaders & 87 & 24.64 \\
& Tourist operators & 83 & 23.51 \\
\hline \multirow{2}{*}{ Level of Education } & Primary-Secondary & 44 & 12.46 \\
& 10th grade-12 grade & 97 & 27.47 \\
& Bachelors & 68 & 19.26 \\
& Masters-Doctoral & 59 & 16.71 \\
& Diploma & 85 & 24.07 \\
\hline
\end{tabular}

\subsection{Data Analysis Process}

A partial least squares (PLS) analysis using the Smart-PLS version 3.0 software (SmarkPLS GmbH, Hamburg, Germany) was utilized to test the hypothesized model. Following the recommended two-stage analytical procedures of Anderson and Gerbing [63], we tested the measurement model and then examined the structural model using a bootstrapping method with a resample size of 5000 [64].

\section{Results}

\subsection{Measurement Model}

Through the measurement model test, we assessed convergent validity and discriminant validity. The convergent validity of the measurement for reflective measures is usually ascertained by examining the loadings, average variance extracted (AVE), and composite reliability (Anderson and Gerbing [63]). The loadings were all higher than 0.5 , the composite reliabilities were all higher than 0.7 , and the AVEs were also higher than 0.5 , as shown in Table 2.

Table 2. Convergent validity (reflective measures).

\begin{tabular}{cccccc}
\hline Construct & Mean & Std. Dev. & Cronbach & CR & AVE \\
\hline Community Empowerment & & & & & \\
Accountability (ACC) & 3.714 & 0.643 & 0.812 & 0.865 & 0.518 \\
Capacity Building (CB) & 3.650 & 0.658 & 0.836 & 0.877 & 0.505 \\
$\quad$ Leader Support (LS) & 2.757 & 0.550 & 0.846 & 0.884 & 0.521 \\
$\quad$ Community Support & 3.279 & 0.545 & 0.766 & 0.841 & 0.516 \\
Sustainable Tourism Development & & & & & \\
Cultural Awareness (CA) & 4.092 & 0.766 & 0.779 & 0.900 & 0.819 \\
Community Resources (CRI) & 4.211 & 0.752 & 0.790 & 0.877 & 0.705 \\
Environmental Education (EE) & 3.989 & 0.628 & 0.803 & 0.859 & 0.504 \\
Economic Planning (EP) & 4.014 & 0.648 & 0.821 & 0.870 & 0.529 \\
Resource Preservation (RP) & 4.015 & 0.684 & 0.870 & 0.898 & 0.525 \\
Stakeholder Inclusion (SI) & 3.952 & 0.665 & 0.847 & 0.887 & 0.567 \\
\hline
\end{tabular}

Note: Std. Dev.—standard deviation.

We modelled community empowerment (three dimensions) and STD (six dimensions) as a type II (reflective-formative) measure following the recommendation of Ziggers and Henseler [65]. To estimate the formative measures, we assessed the weights, $t$-values and the variance inflation factor (VIF). 
As described in Table 3, all the weights were significant, and the VIF values were all lower than 5 [64], suggesting that they were acceptable.

Table 3. Convergent validity (formative measures).

\begin{tabular}{cccc}
\hline Construct & Weights & $t$-Values & VIF \\
\hline Community Empowerment & & & \\
$\mathrm{ACC} \rightarrow$ Community Empowerment & 0.377 & $15.328^{* *}$ & 1.524 \\
$\mathrm{CB} \rightarrow$ Community Empowerment & 0.436 & $20.024^{* *}$ & 1.630 \\
$\mathrm{LS} \rightarrow$ Community Empowerment & 0.395 & $17.436^{* *}$ & 1.559 \\
Sustainable Tourism Development & & & \\
$\mathrm{CA} \rightarrow$ Sustainable Tourism Development & 0.092 & $17.405^{* *}$ & 1.942 \\
$\mathrm{CRI} \rightarrow$ Sustainable Tourism Development & 0.119 & $18.778^{* *}$ & 1.901 \\
$\mathrm{EE} \rightarrow$ Sustainable Tourism Development & 0.208 & $27.575^{* *}$ & 3.892 \\
$\mathrm{EP} \rightarrow$ Sustainable Tourism Development & 0.213 & $27.596^{* *}$ & 3.015 \\
$\mathrm{RP} \rightarrow$ Sustainable Tourism Development & 0.291 & $28.637^{* *}$ & 3.450 \\
$\mathrm{SI} \rightarrow$ Sustainable Tourism Development & 0.229 & $24.639^{* *}$ & 3.207 \\
\hline
\end{tabular}

Note: ACC—accountability; CB—capacity building; LS—leader support; CA—cultural awareness; CRI—community resource identification; EE-environmental education; $\mathrm{EP}$ - economic planning; RP-resource preservation; SI-stakeholder inclusion; ${ }^{* *} p<0.01$.

The discriminant validity of the measures (the degree to which items differentiate among constructs or measure distinct concepts) was examined by following the criterion [66] of comparing the correlations between constructs and the square root of the AVE for that construct (see Table 4). All the values on the diagonals were greater than the corresponding row and column values, indicating that the measures were discriminant. There has been a recent criticism towards the Fornell and Larcker [66] criterion, in that it cannot reliably detect the lack of discriminant validity in common research situations [67]. Hence, an alternative approach was suggested based on the multitrait-multimethod matrix to assess discriminant validity, i.e., the heterotrait-monotrait (HTMT) ratio of correlations. We used the criterion of HTMT value of 0.85 cut-off [68] All the HTMT ratios were well below 0.85 (community empowerment-community support (CE-CS): 0.326, CE-STD: 0.557, and CS-STD: 0.467), indicating that discriminant validity was ascertained.

Table 4. Discriminant validity.

\begin{tabular}{cccc}
\hline Construct & $\mathbf{1}$ & $\mathbf{2}$ & $\mathbf{3}$ \\
\hline 1. Community Empowerment & Formative & & \\
2. Community Support & 0.326 & 0.718 & \\
3. Sustainable Tourism Development & 0.594 & 0.466 & Formative \\
\hline
\end{tabular}

\subsection{Structural Model}

To assess the structural model, Hair et al. [64] suggested looking at the $\mathrm{R}^{2}$, the beta, and the corresponding $t$-values via a bootstrapping procedure with a resample size of 5000. They also suggested that, in addition to these basic measures, researchers should also report the effect sizes $\left(f^{2}\right)$.

First, we looked at the effects of the independent variable on the dependent variable. Community empowerment $\left(\beta=0.494, t=8.848, f^{2}=0.571\right)$ and community support $\left(\beta=0.305, t=6.940, f^{2}=0.429\right)$ had positive effects on STD and explained $43.6 \%$ of the variance in STD.

Meanwhile, community empowerment $\left(\beta=0.326, t=5.249, f^{2}=0.199\right)$ also had a positive effect on STD and explained $10.6 \%$ of the variance in STD. This supports H1, H2 and H3 of our study.

Next, we looked at the mediating effect of community support on the community empowerment-STD relationship. The indirect effect of community empowerment on STD via community support $\left(\beta=0.099, t=4.547, B C_{0.95} L L=0.057\right.$ and $\left.B C_{0.95} U L=0.138\right)$ was significant. Additionally, as suggested by Preacher and Hayes [69,70], the indirect effects did not straddle zero, 
which indicated the action of a mediating effect. Thus, we can conclude that the mediating effect was statistically significant, and, hence, that $\mathrm{H} 4$ is also supported. Table 5 describes the results of hypotheses test.

Table 5. Hypotheses testing.

\begin{tabular}{|c|c|c|c|c|c|c|}
\hline \multirow{2}{*}{ Hypothesis } & \multirow{2}{*}{ Std. Estimate } & \multirow{2}{*}{ Std. Error } & \multirow{2}{*}{$\mathbf{t}$} & \multirow{2}{*}{ Decision } & \multicolumn{2}{|c|}{ 95\% Boot CI } \\
\hline & & & & & LL & UL \\
\hline $\mathrm{H} 1: \mathrm{CE} \rightarrow \mathrm{STD}$ & 0.494 & 0.056 & $8.848^{* *}$ & Supported & 0.368 & 0.592 \\
\hline $\mathrm{H} 2: \mathrm{CE} \rightarrow \mathrm{CS}$ & 0.326 & 0.062 & $5.249 * *$ & Supported & 0.189 & 0.424 \\
\hline H3: CS $\rightarrow$ STD & 0.305 & 0.044 & $6.940^{* *}$ & Supported & 0.209 & 0.387 \\
\hline $\mathrm{H} 4: \mathrm{CE} \rightarrow \mathrm{CS} \rightarrow \mathrm{STD}$ & 0.099 & 0.022 & $4.547^{* *}$ & Supported & 0.057 & 0.138 \\
\hline
\end{tabular}

\section{Discussion}

This study contributes to tourism literature by developing a model that links important variables of community-based tourism to the sustainability of tourism development.

The current research finding shows that community empowerment has a strong impact in facilitating STD. In the history of STD research, residents' empowerment has been identified as a key driver in developing sustainable tourism $[9,22,27,32,45,71]$ for the long lasting economic, social and cultural lives of community members. Community empowerment gives power to the local residents in making decisions to implement plans and policies for STD, thus raising the community's welfare [30]. This study replicated and expanded the existing literature by testing the theory using data empirically collected from residents in the context of community-based tourism in a least developed country.

The result for the data analysis revealed that there is a significant positive relationship between community empowerment and community support for tourism. That is, community empowerment is considered a prerequisite for community support for tourism, as increasing information and capacity followed by participation in decision making for local initiates for tourism development increase resident support for tourism. The findings support social exchange theory, which postulates that power is central to social exchange because it determines a community's ability to benefit from tourism and support tourism development [43]. Communities with a chance to participate in the planning and management for tourism development initiatives determine their support for tourism [32]. The findings highlight the significant relationship between community support for tourism and STD. The study findings are consistent with previous findings $[43,45,46]$. The result implies that the objective of sustainable tourism cannot be achieved without the support for tourism of the local community.

Community support for tourism significantly and partially mediates the effect of community empowerment on STD. Previous studies have shown a mediating effect of community support between perceived tourism impact and support for tourism planning [35,43,53,72]. The findings of this study also highlight community support's bridging role from community empowerment to STD. That is, residents' community support for tourism is strengthened when there are leaders' support for residents, residents' strong accountability, and residents' capability building, thus leading the community to successful STD.

\section{Conclusions}

The study modeled community empowerment on STD in the context of tourism and investigated the mediating role of community support for tourism using data collected from 353 respondents of Gilgit Baltistan, Pakistan. The present research aimed to employ community empowerment as a factor influencing the sustainability of tourism development through support of local communities. The present study focused on the empowerment of the local community and its contribution in achieving the sustainability of tourism development. The findings of the study have revealed a proper 
channel from community empowerment to STD. The results have further revealed that empowerment is an important predictor of a community's support and STD. The current study can be concluded as a practical and theoretical contribution. The practical contribution section discusses the applicability of this study's findings in the policy and management of tourism, whereas the theoretical contribution section addresses the knowledge gap that is being filled by the current research's findings.

\subsection{Practical Implications}

Local communities can retain the benefits from STD by supporting STD initiatives. Community empowerment is at the philosophical core of STD [43]. Empowered local residents assist in mitigating the negative impact of tourism that leads to the sustainability of tourism development. Therefore, tourism planners need to empower local communities by involving them in making decisions for STD projects. In the tourism development process, it is necessary for local communities to have appropriate knowledge, skills and abilities to participate in STD initiatives. Thus, it has been suggested that NGOs and local governments should continuously educate local residents to increase the awareness among community members about STD. More practically, the local residents and leaders can organize tourism advisory committees, training programs, workshops, focus groups and public hearings, thus leading to developing and sharing the skills and capabilities among local people.

Community leaders and local politicians should actively play a role as a bridge between external and internal agents. They should gain the trust of community members by convincing them that tourism development brings benefits to local communities rather than impose costs. Community members will enthusiastically participate in and support tourism development initiatives when they perceive that their interests are valued [73,74]. In addition, governments should ensure the transparency of tourism planning and management to gain the support of local communities. As tourism is a service-based industry, community support for tourism is important for the success of the tourism industry [75]. Planners can use the findings of the current study to gain more support from the local community for tourism development.

\subsection{Theoretical Contribution}

Generally, empowerment has been used as single dimensional concept based on political power. The current study used empowerment as a multidimensional concept, as proposed by previous research [37]. Moreover, the study results theoretically contribute by elaborately establishing an empirical relationship between community empowerment and STD, thus filling the literature gap on the need of quantitative research to measure empowerment and its role in STD [15]. Community members cannot participate in tourism development initiatives until they have the abilities and support from local leaders. In this research, leaders' support was considered to be an important dimension of community empowerment, which has been neglected in the tourism literature. As such, the current study fulfills the gap identified by previous research [76,77].

\subsection{Limitations and Future Research}

Although the current research investigated the direct effect of community empowerment on community support for tourism, future studies can consider residents' attitude toward tourism as potential mediators between community empowerment and community support for tourism by employing the perceptions-attitudes-behaviors sequence suggested by Martín, Garcia de los Sánchez and Herreto [78]. The current study focused on local residents as respondents, whereas future studies can consider different groups, such as NGOs and tourism officials, for multi-group analysis.

Author Contributions: Conceptualization, S.K. and M.S.A.; methodology, T.R.; writing—original draft preparation, S.K., I.K.; writing—review and editing, J.H.; supervision, I.K.

Funding: This research received no external funding.

Conflicts of Interest: The authors declare no conflict of interest. 


\section{References}

1. Asmelash, A.G.; Kumar, S. Assessing progress of tourism sustainability: Developing and validating sustainability indicators. Tour. Manag. 2019, 71, 67-83. [CrossRef]

2. Gius, C. Facing the pain of others: Perspectives on international volunteer tourism between agency and spectatorship. Curr. Issues Tour. 2017, 20, 1620-1632. [CrossRef]

3. Zhao, S.N.; Timothy, D.J. Governance of red tourism in China: Perspectives on power and guanxi. Tour. Manag. 2015, 46, 489-500. [CrossRef]

4. Dodds, R.; Ali, A.; Galaski, K. Mobilizing knowledge: Determining key elements for success and pitfalls in developing community-based tourism. Curr. Issues Tour. 2018, 21, 1547-1568. [CrossRef]

5. Lee, T.H.; Jan, F.H. Can community-based tourism contribute to sustainable development? Evidence from residents' perceptions of the sustainability. Tour. Manag. 2019, 70, 368-380. [CrossRef]

6. Ellis, S.; Sheridan, L. The role of resident perceptions in achieving effective community-based tourism for least developed countries. Anatolia 2015, 26, 244-257. [CrossRef]

7. Sebele, L.S. Community-based tourism ventures, benefits and challenges: Khama rhino sanctuary trust, central district, Botswana. Tour. Manag. 2010, 31, 136-146. [CrossRef]

8. Manyara, G.; Jones, E. Community-based tourism enterprises development in Kenya: An exploration of their potential as avenues of poverty reduction. J. Sustain. Tour. 2007, 15, 628-644. [CrossRef]

9. Boley, B.B.; McGehee, N.G.; Perdue, R.R.; Long, P. Empowerment and resident attitudes toward tourism: Strengthening the theoretical foundation through a Weberian lens. Ann. Tour. Res. 2014, 49, 33-50. [CrossRef]

10. Choi, H.S.C.; Sirakaya, E. Measuring residents' attitude toward sustainable tourism: Development of sustainable tourism attitude scale. J. Travel Res. 2005, 43, 380-394. [CrossRef]

11. Di Castri, F. Sustainable tourism in small islands: Local empowerment as the key factor. INSUL. PARIS 2004, $13,49$.

12. Kline, C.; McGehee, N.; Delconte, J. Built capital as a catalyst for community-based tourism. J. Travel Res. 2019, 58, 899-915. [CrossRef]

13. Nunkoo, R.; Smith, S.L. Political economy of tourism: Trust in government actors, political support, and their determinants. Tour. Manag. 2013, 36, 120-132. [CrossRef]

14. Hall, J.K.; Daneke, G.A.; Lenox, M.J. Sustainable development and entrepreneurship: Past contributions and future directions. J. Bus. Ventur. 2010, 25, 439-448. [CrossRef]

15. Boley, B.B.; Maruyama, N.; Woosnam, K.M. Measuring empowerment in an eastern context: Findings from Japan. Tour. Manag. 2015, 50, 112-122. [CrossRef]

16. Li, Y. Exploring Community Tourism in China: The Case of Nanshan Cultural Tourism Zone. J. Sustain. Tour. 2004, 12, 175-193. [CrossRef]

17. Hatton, M.J. Community-Based Tourism in the Asia-Pacific; School of Media Studies, Humber College: Toronto, ON, Canada, 1999.

18. Gurung, D.B.; Seeland, K. Ecotourism in Bhutan: Extending its benefits to rural communities. Ann. Tour. Res. 2008, 35, 489-508. [CrossRef]

19. Lepp, A. Attitudes towards initial tourism development in a community with no prior tourism experience: The case of Bigodi, Uganda. J. Sustain. Tour. 2008, 16, 5-22. [CrossRef]

20. Sebastian, L.M.; Rajagopalan, P. Socio-cultural transformations through tourism: A comparison of residents' perspectives at two destinations in Kerala, India. J. Tour. Cult. Chang. 2009, 7, 5-21. [CrossRef]

21. Din, K.H. Dialogue with the hosts: An educational strategy towards sustainable tourism. In Tourism in South-East Asia; Routledge: London, UK, 2018.

22. Hughes, E.; Scheyvens, R. Development Alternatives in the Pacific: How Tourism Corporates Can Work More Effectively with Local Communities. Tour. Plan. Dev. 2018, 15, 516-534. [CrossRef]

23. Lee, T.H. Influence analysis of community resident support for sustainable tourism development. Tour. Manag. 2013, 34, 37-46. [CrossRef]

24. Mathew, P.V.; Sreejesh, S. Impact of responsible tourism on destination sustainability and quality of life of community in tourism destinations. J. Hosp. Tour. Manag. 2017, 31, 83-89. [CrossRef]

25. Ahmad, M.S.; Talib, N.B.A. Empowering local communities: Decentralization, empowerment and community driven development. Qual. Quant. 2015, 49, 827-838. [CrossRef] 
26. Byrd, E.T. Stakeholders in sustainable tourism development and their roles: Applying stakeholder theory to sustainable tourism development. Tour. Rev. 2007, 62, 6-13. [CrossRef]

27. Bello, F.G.; Lovelock, B.; Carr, N. Enhancing community participation in tourism planning associated with protected areas in developing countries: Lessons from Malawi. Tour. Hosp. Res. 2018, 18, 309-320. [CrossRef]

28. Shakeela, A.; Weaver, D. Participatory planning and tourism development in the Maldives: A prerequisite of sustainability? In Managing Asian Destinations; Springer: Singapore, 2018; pp. 73-85.

29. Strzelecka, M.; Boley, B.B.; Strzelecka, C. Empowerment and resident support for tourism in rural Central and Eastern Europe (CEE): The case of Pomerania, Poland. J. Sustain. Tour. 2017, 25, 554-572. [CrossRef]

30. Sutawa, G.K. Issues on Bali tourism development and community empowerment to support sustainable tourism development. Procedia Econ. Financ. 2012, 4, 413-422. [CrossRef]

31. Sood, J.; Lynch, P.; Anastasiadou, C. Community non-participation in homestays in Kullu, Himachal Pradesh, India. Tour. Manag. 2017, 60, 332-347. [CrossRef]

32. Nunkoo, R.; So, K.K.F. Residents' support for tourism: Testing alternative structural models. J. Travel Res. 2016, 55, 847-861. [CrossRef]

33. Strzelecka, M.; Boley, B.B.; Woosnam, K.M. Place attachment and empowerment: Do residents need to be attached to be empowered? Ann. Tour. Res. 2017, 66, 61-73. [CrossRef]

34. Budeanu, A.; Miller, G.; Moscardo, G.; Ooi, C.S. Sustainable Tourism, Progress, Challenges and Opportunities: An Introduction. J. Clean. Prod. 2016, 111, 285-294. [CrossRef]

35. Rasoolimanesh, S.M.; Ringle, C.M.; Jaafar, M.; Ramayah, T. Urban vs. rural destinations: Residents' perceptions, community participation and support for tourism development. Tour. Manag. 2017, 60, 147-158. [CrossRef]

36. Sofield, T.H. Empowerment for Sustainable Tourism Development; Pergamon: Oxford, UK, 2003.

37. Butler, G. Fostering community empowerment and capacity building through tourism: Perspectives from Dullstroom, South Africa. J. Tour. Cult. Chang. 2017, 15, 199-212. [CrossRef]

38. Mendoza-Ramos, A.; Prideaux, B. Assessing ecotourism in an Indigenous community: Using, testing and proving the wheel of empowerment framework as a measurement tool. J. Sustain. Tour. 2018, 26, 277-291. [CrossRef]

39. Chen, N.; Hsu, C.H.; Li, X.R. Feeling superior or deprived? Attitudes and underlying mentalities of residents towards Mainland Chinese tourists. Tour. Manag. 2018, 66, 94-107. [CrossRef]

40. Eusébio, C.; Vieira, A.L.; Lima, S. Place attachment, host-tourist interactions, and residents' attitudes towards tourism development: The case of Boa Vista Island in Cape Verde. J. Sustain. Tour. 2018, 26, 890-909. [CrossRef]

41. McCaughey, R.; Mao, I.; Dowling, R. Residents' perceptions towards cruise tourism development: The case of Esperance, Western Australia. Tour. Recreat. Res. 2018, 43, 403-408. [CrossRef]

42. Gursoy, D.; Jurowski, C. Resident attitudes in relation to distance from tourist attractions. Ann. Tour. Res. 2002, 31, 296-312.

43. Nunkoo, R.; Ramkissoon, H. Residents' satisfaction with community attributes and support for tourism. J. Hosp. Tour. Res. 2011, 35, 171-190. [CrossRef]

44. Suess, C.; Baloglu, S.; Busser, J.A. Perceived impacts of medical tourism development on community wellbeing. Tour. Manag. 2018, 69, 232-245. [CrossRef]

45. Panyik, E. Rural tourism governance: Determinants of policy-makers' support for tourism development. Tour. Plan. Dev. 2015, 12, 48-72. [CrossRef]

46. Canalejo, A.M.C.; Tabales, J.N.; López, J.M.C.; Fuentes-García, F.J. Resident perceptions of community tourism in Cape Verde. Tour. Cult. Commun. 2015, 15, 103-119. [CrossRef]

47. Park, D.B.; Lee, K.W.; Choi, H.S.; Yoon, Y. Factors influencing social capital in rural tourism communities in South Korea. Tour. Manag. 2012, 33, 1511-1520. [CrossRef]

48. Bittar Rodrigues, C.; Prideaux, B. A management model to assist local communities developing community-based tourism ventures: A case study from the Brazilian Amazon. J. Ecotour. 2018, 17, 1-19. [CrossRef]

49. Chen, Z.; Li, L.; Li, T. The organizational evolution, systematic construction and empowerment of Langde Miao's community tourism. Tour. Manag. 2017, 58, 276-285. [CrossRef] 
50. Cheng, T.M.; Wu, H.C.; Wang, J.T.M.; Wu, M.R. Community Participation as a mediating factor on residents' attitudes towards sustainable tourism development and their personal environmentally responsible behaviour. Curr. Issues Tour. 2019, 22, 1764-1782. [CrossRef]

51. Moghavvemi, S.; Woosnam, K.M.; Paramanathan, T.; Musa, G.; Hamzah, A. The effect of residents' personality, emotional solidarity, and community commitment on support for tourism development. Tour. Manag. 2017, 63, 242-254. [CrossRef]

52. Selin, S. Elaborating the Role of Backbone Leadership Organizations in Sustainable Tourism Development: The Monongahela River Valley Coalition. Sustainability 2017, 9, 1367. [CrossRef]

53. Nunkoo, R.; Ramkissoon, H. Power, trust, social exchange and community support. Ann. Tour. Res. 2012, 39, 997-1023. [CrossRef]

54. Satarat, M.N. Sustainable Management of Community-Based Tourism in Thailand (Unpublished doctoral dissertation). 2010. Available online: http://libdcms.nida.ac.th/thesis6/2010/b166706.pdf (accessed on 7 November 2019).

55. Scott, N.; Marzano, G. Governance of tourism in OECD countries. Tour. Recreat. Res. 2015, 40, 181-193. [CrossRef]

56. Park, D.B.; Nunkoo, R.; Yoon, Y.S. Rural residents' attitudes to tourism and the moderating effects of social capital. Tour. Geogr. 2015, 17, 112-133. [CrossRef]

57. Cárdenas, D.A.; Byrd, E.T.; Duffy, L.N. An exploratory study of community awareness of impacts and agreement to sustainable tourism development principles. Tour. Hosp. Res. 2015, 15, 254-266. [CrossRef]

58. Theobald, W.F. Global Tourism, 2nd ed.; Butterworth-Heinemann: Oxford, UK, 2001.

59. Ven, S. Host residents' attitude toward community-based ecotourism: Empirical study in southwestern Cambodia. J. Tour. Hosp. 2015, 4, 1-11.

60. Simpson, M. Community Benefit Tourism Initiatives-A conceptual oxymoron? Tour. Manag. 2008, 29 , 1-18. [CrossRef]

61. Tosun, C. Limits to community participation in the tourism development process in developing countries. Tour. Manag. 2000, 21, 613-633. [CrossRef]

62. Wang, F.; Deng, Z.; Petrick, J.F. Exploring the formation mechanisms of urban residents' travel behaviour in China: Perceptions of travel benefits and travel constraints. J. Travel Tour. Mark. 2018, 35, 909-921. [CrossRef]

63. Anderson, J.C.; Gerbing, D.W. Structural equation modeling in practice: A review and recommended two-step approach. Psychol. Bull. 1988, 103, 411. [CrossRef]

64. Hair, J.F., Jr.; Sarstedt, M.; Ringle, C.M.; Gudergan, S.P. Advanced Issues in Partial Least Squares Structural Equation Modeling; Sage Publications: Thousand Oaks, CA, USA, 2017.

65. Ziggers, G.W.; Henseler, J. The reinforcing effect of a firm's customer orientation and supply-base orientation on performance. Ind. Mark. Manag. 2016, 52, 18-26. [CrossRef]

66. Fornell, C.; Larker, D. Structural equation modeling and regression: Guidelines for research practice. J. Mark. Res. 1981, 18, 39-50. [CrossRef]

67. Henseler, J.; Ringle, C.M.; Sarstedt, M. A new criterion for assessing discriminant validity in variance-based structural equation modeling. J. Acad. Mark. Sci. 2015, 43, 115-135. [CrossRef]

68. Kline, R.B. Principles and Practice of Structural Equation Modeling, 3rd ed.; Guilford: New York, NY, USA, 2011.

69. Preacher, K.J.; Hayes, A.F. SPSS and SAS procedures for estimating indirect effects in simple mediation models. Behav. Res. Methods Instrum. Comput. 2004, 36, 717-731. [CrossRef] [PubMed]

70. Preacher, K.J.; Hayes, A.F. Asymptotic and resampling strategies for assessing and comparing indirect effects in multiple mediator models. Behav. Res. Methods 2008, 40, 879-891. [CrossRef] [PubMed]

71. Nunkoo, R. Tourism development and trust in local government. Tour. Manag. 2015, 46, 623-634. [CrossRef]

72. McGehee, N.G.; Andereck, K.L. Factors predicting rural residents' support of tourism. J. Travel Res. 2004, 43, 131-140. [CrossRef]

73. Özel, Ç.H.; Kozak, N. An exploratory study of resident perceptions toward the tourism industry in Cappadocia: A Social Exchange Theory approach. Asia Pac. J. Tour. Res. 2017, 22, 284-300. [CrossRef]

74. Wu, J.M.; Tsai, H.; Lee, J.S. Unraveling public support for casino gaming: The case of a casino referendum in Penghu. J. Travel Tour. Mark. 2017, 34, 398-415. [CrossRef]

75. Kafashpor, A.; Ghasempour Ganji, S.F.; Sadeghian, S.; Johnson, L.W. Perception of tourism development and subjective happiness of residents in Mashhad, Iran. Asia Pac. J. Tour. Res. 2018, 23, 521-531. [CrossRef] 
76. Armstrong, R. An analysis of the conditions for success of community-based tourism enterprises. ICRT Occas. Paper 2012, 21, 1-52.

77. Moscardo, G. Sustainable tourism innovation: Challenging basic assumptions. Tour. Hosp. Res. 2008, 8, 4-13. [CrossRef]

78. Martín, H.S.; Garcia de los Sánchez, M.M.; Herrero, Á. Residents' attitudes and behavioural support for tourism in host communities. J. Travel Tour. Mark. 2018, 35, 231-243. [CrossRef] 